\title{
Effects of Structural Intellectual Capital on The Innovation Capacity of Public Administration
}

\author{
Rodrigo Belmonte da Silva*1, Carlos Maria Fernández Jardón ${ }^{2}$, Lucas Veiga Avila ${ }^{3 *}$
}

\begin{abstract}
Structural capital is one of the elements of intellectual capital and measuring it in local public administration contributes to assessing value for society. This article analyzes the effects of structural intellectual capital on the innovation capacity of public administration in a Latin American city. The research was carried out with civil servants who hold management positions in the City Hall of the researched city. It was used multivariate exploratory analysis, principal component analysis, correlation and linear regression to statistically organize the data. The main results are that structural intellectual capital has a positive, significant and direct influence on the capacity for innovation in public administration. For public managers, the study demonstrated that investment in structural capital can have direct and proportional effects on the ability to innovate in services and processes, organizational and institutional. Therefore, investments in structure, processes, and organizational philosophy in public administration tend to improve managers' ability to innovate. It is important to highlight that structural intellectual capital aligned with innovation has the potential to significantly improve technology, services, processes, and meeting social demands for the local community.
\end{abstract}

Keywords: Knowledge management; intellectual capital; structural capital; innovation in the public sector; innovation capacity

Submitted: May $16^{\text {th }}, 2021 /$ Approved: October $26^{\text {th }}, 2021$

\section{Introduction}

Knowledge management in the public sector has the potential to influence and improve renewal processes, and increase efficiency in the public sector, in all its areas (Massaro, Dumay, and Garlatti, 2015). Unlike private administration, the public area deals with a broader complex environment, involving a larger number of stakeholders and variables (Demircioglu and Audretsch, 2018) such as: social inequalities, deficient public security, environmental and epidemic issues, as for example Covid-19 these days. Possibly, the stock of knowledge in public administration constitutes an important factor to better withstand these crises.

The sum of organizational knowledge is known by part of the specialized literature (Stewart 1998; Edvinsson and Malone, 1998; Ross, 2017) as intellectual capital. The fourth phase of research on the topic, defines this capital as an integrated dynamic of knowledge, experience, intellectual property, organizational practices, information and external relationships, resulting from intangible assets, to create value (Dumay, 2016). In this sense, structural capital, as an element of intellectual capital, is responsible for formalizing individual knowledge into organizational knowledge (Bontis et al., 1999) and presents internal aspects such as: management philosophy, managerial processes, organizational culture, information systems, etc. (Jardón and Silva, 2020).

Relating structural capital to the ability to innovate is relevant in public administration because innovation is a process of generating and implementing new ideas with a view to creating value for society (European Commission, 2013). Innovation capacity, the phase prior to innovation, is understood as the ability/ability to develop new services, processes, organizational and institutional strategic changes, based on the knowledge, behavior, skills, routines, processes and learning and governance mechanisms of local/municipal public administrations (Meirelles and Camargo, 2014; Zollo and Winter, 2002; Teece et al., 2007; Wang and Ahmed, 2007; Lewis et al., 2018; Demircioglu and Audretsch, 2018).

Studies that address the relationship between structural capital and innovation capacity are scarce, and considering local public administration, are novel. Rodrigues et al., (2011) cite research that shows that structural capital influences entrepreneurial innovation capacity (Viedma, 2002, Martin de Castro et al., 2009; Díaz et al, 2006). All of these findings demonstrate that as structural capital increases, innovative capability in the organization increases. Rodrigues et al., (2011) in research in the Galicia region (Northern Spain) in the automotive sector, state that structural capital influences differently each type of innovative capability (product-process and management). In Taiwan, a positive and significant correlation was also found between structural capital and innovation performance (Wu, Lin \& Hsu, 2007).

However, in local public administration, some more recent research (Rossi et al., 2016; Bonemberguer et al., 2019) despite proposing quantitative structural capital constructs, does not record correlations with other dependent variables. It was Kamaruddin and Abeysekera (2013) in research in Malaysia, who were concerned with relating measures of intellectual capital and organizational performance, in local governments, however, nothing specific, relating to innovation.

(1) Department of Management and Business, Farroupilha Federal Institute - IFFAR, São Vicente do Sul, Brazil

(2) Departamento de Economía Aplicada - Universidad de Vigo, Vigo, España

IDLAB, and National Research University Higher School of Economics Perm, Russian Federation

(3) Federal University of Santa Maria - UFSM, Cachoeira do Sul, Brazil

*Corresponding author: rodrigo.silva@iffarroupilha.edu.br 
Although the themes are correlated in private management, the public sector does not register in the literature, research that studies the effects of structural capital and its factors, in different dimensions of innovation capacity. For this reason we propose the question-problem: does the structural capital influence the innovation capacity in the local public administration?

The universe of the research was a City Hall in Latin America, specifically, in the southern region of Brazil, having as subjects, the municipal managers in that country, who have legal stability in public employment, and possibly, therefore, are less politically influential (Ramírez et. al., 2020). In addition, the site was chosen because its management is based on a strategic planning that has been in effect for over 10 years ( $3 \mathrm{rd}$ consecutive municipal administration), theoretically configuring itself as a fundamental intangible to boost organizational competitiveness, directly impacting the improvement of intellectual capital processes (Galego et. al., 2020).

Therefore, the study has the intention to contribute with the theory, testing components of structural capital and innovation capacity, besides analyzing the existence of influence between them, contributing, in a practical way, in knowledge management strategies for the public administration researched.

\section{Structural Intellectual Capital and Innovation Capability}

\subsection{Framework for Innovation and Innovation Capacity in Local Public Administration}

The existence of a structure for innovation is characterized by the granting of autonomy, flexible controls, fluid horizontal communication, valuing knowledge and experience, and informality in personal relationships. It is possible to say, that the organization that works in this conjuncture, has an organic structure that allows faster responses to changes in the external environment (Valladares et al., 2016) and, consequently, with greater possibilities to innovate. Although the movement of co-creation and decentralized decision-making practices has grown, through the collaborative economy, public administrations are still seen as excessively bureaucratic (Alosani et al., 2019), as is the case in Brazil. Many works have already pointed out positive influence between structure and innovation capacity (Baldridge y Burnham, 1975; Damanpour, 1991; McCann, 1991; Wan et al., 2005; Subramanian y Nilakanta, 1996), although in other economic contexts. Therefore, it is relevant to study whether the elements of internal intangibles, such as the elements that form the organizational structure in public administration, are somehow able to influence its ability to innovate, according to the organization presented by figure 1. With these arguments we propose the first research hypothesis:

H1. The framework for innovation influences the capacity to innovate in local public administration.
Figure 1: Framework - Proposed elements of Structural Capital (Structure for innovation) and Innovation Capacity in Local Public Administration.

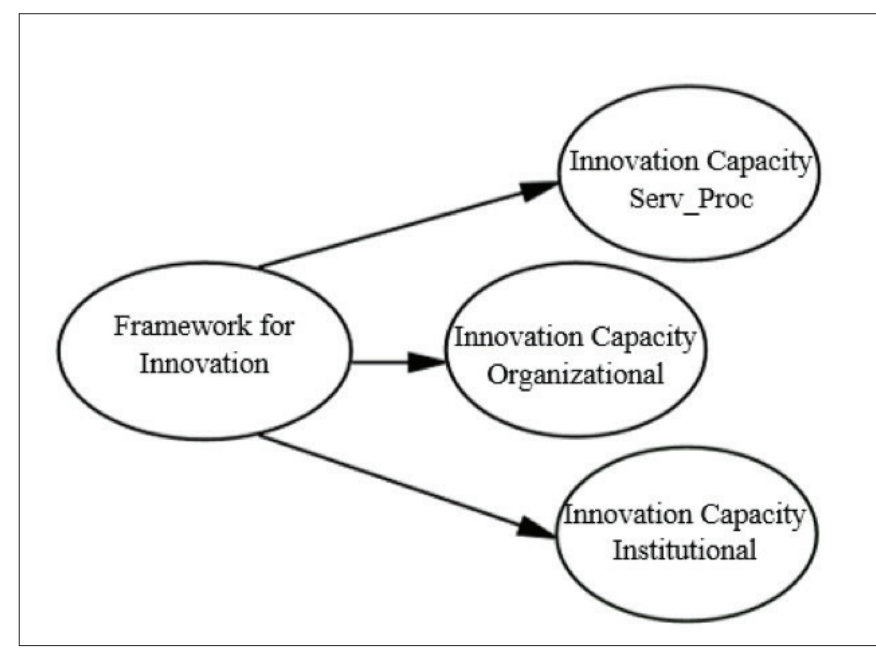

\subsection{Processes for Innovation and Innovation Capacity in Local Public Administration}

By internal processes is meant the "set of activities that configure organizational operations directed to both internal and external customers" (IADE, 2011. p.19). The relationship between internal processes and innovation is broad in the business environment, but not very solid in the public sector. Valladares et al. (2014) considers that innovation capacity is the result of a set of routines (Zollo and Winter, 2002). These include strategic intent to innovate, people management for innovation, strategic technology management, and project management. On the other hand, unique studies in local public administration (Lewis et al.,2018; Grčić and Samaržija, 2016; Demircioglu- and Audretsch, 2018) have resulted in a positive series between internal process factors such as budget, organizational structure of the municipality, municipal strategic plan, people management and their positive relationships with the ability to innovate of public administrations in cities such as Barcelona, Copenhagen and Rotterdam (Lewis et al.,2018). If, on the one hand, Lewis et al.s (2018) studies indicate promising pathways and process structure for local public administration. Other research (Valladares et al., 2014) even citing the public sector, still focuses on business culture, far from the reality of municipalities. In this way, we expect to confirm important and influential elements, in our view, for improving the ability to innovate in public administrations, still identified with the excessively bureaucratic, as is the case of Latin American municipalities in general. Figure 2 suggests a preliminary proposal for the organization of relevant elements, correlated to the dimensions of innovation in this specific public area. In this vein, the research proposes the following research hypothesis:

H2. The processes for innovation influence the capacity for innovation in local public administration. 
Figure 2: Framework - Proposed elements of Structural Capital (Processes for innovation) and Innovation Capacity in Local Public Administration.

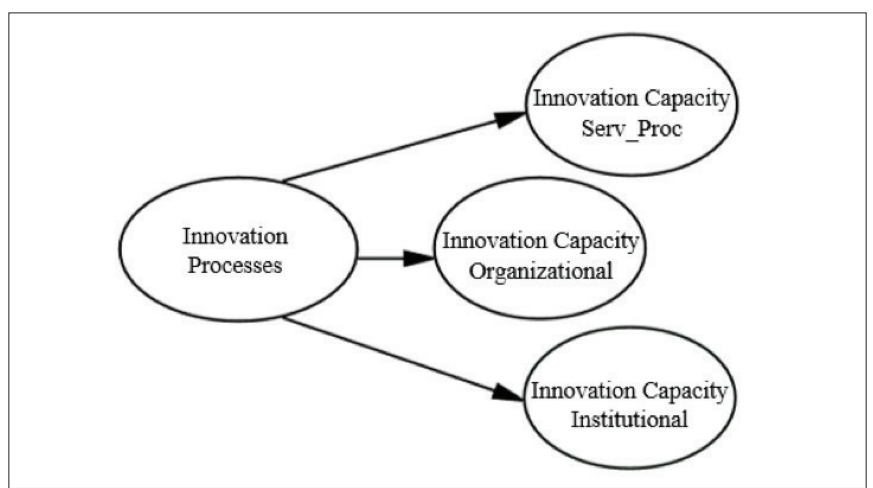

2.3 Organizational Philosophy and Innovation Capacity in Local Public Administration

Vision and values, are part of the philosophy of organizations (IADE, 2011). It is possible to state that the statement of both, translate the organizational strategic intent to some extent. Understanding whether these factors influence organizational behavior, encourage structural, routine or process changes, justifies detailed research into their relationship with the ability to innovate. When employees have clear awareness of organizational mission and goals and have innovation as an integral part of strategies, there is a guiding factor determining change (Molina-Palma, 2004). An example is the citation of the intention to innovate, present in government plans, or in the vision statements of strategic planning, in local public administrations. Organizational values are essential, determining sources of value generation within an organization and allow the development of new competencies (Bontis et al., 1999). Similarly the cognitive and emotional elements, assumptions, belief systems and behavioral norms that shape thinking and action, influence the state of mind (climate) for innovative action (Jassawalla and Sashittal, 2003). The models of intangible management, and the construction of indicators, based on balanced scorecard (Kaplan and Norton, 1996, 1997, 1999), in the late 1990s and early 2000s, translate this reality, when it proposes a cause-and-effect relationship between dimensions of organizational knowledge, to achieve the organization's vision of the future. In this sense the study proposes the following hypothesis:

H3. The organizational philosophy influences the innovation capacity in local public administration.

Figure 3: Framework - Proposed Elements Structural Capital (Organizational Philosophy) and Innovation Capacity in Local Public Administration.

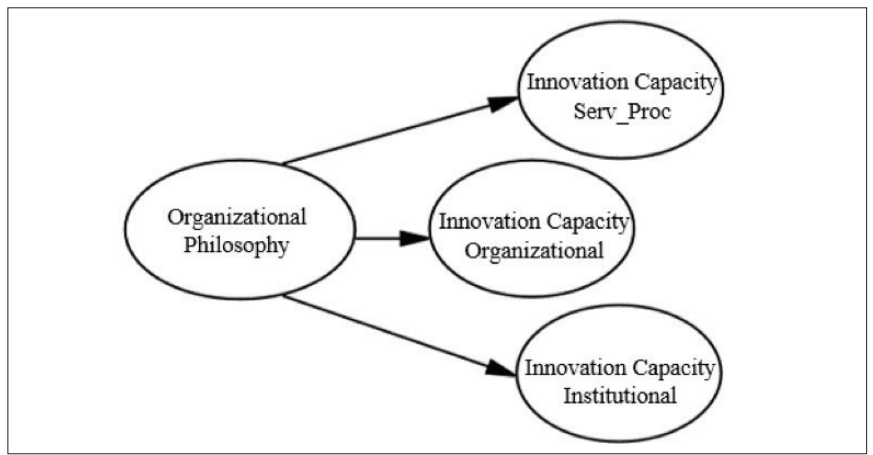

\section{Method}

\subsection{Data}

To test the central hypothesis, we sought to investigate we employed a questionnaire as a research instrument. The universe of study was the Prefeitura Municipal de Santiago, a municipality located in the central-western region of Rio Grande do Sul, southern region of Brazil, in Latin America. The organization's managers, leaders and managers of sectors, departments, secretaries and principals and vice principals of the municipal schools were interviewed.

Primary data were obtained between the months of December 2019 and February 2020, through directed and unidentified questionnaires. A total of 158 returns were received, representing a response rate of $87.7 \%$. All offices, departments, sectors, and schools were represented showing a response rate above $75 \%$.

The research questionnaire was prepared based on theoretical and empirical studies about the themes: Structural Intellectual Capital and Innovation in the Public Sector, having been tested, first, with a restricted number of servers for adjustments and validation of the questions, besides checking their clarity and understanding. The choice of research subjects considered the degree of strategic and tactical leadership, interviewing servers who participate directly in organizational management and public policies, and, presumably, aware of the City Hall Management Model.

\subsection{Measures}

The structural capital and innovation capacity components can be considered multidimensional, therefore, composed of multiple items with the intention of evaluating them together.

Innovation Capability is composed of 8 items, divided into 3 factors, as shown in Table 1:

- Service and Process Innovation Capability - ability to create or modify ways in which services and or process are designed or provided to users (Hartley, 2005; Koch et al., 2005).

- Organizational Innovation Capability - the ability to create or modify contexts, goals, concepts, or purposes (Hartley, 2005; Koch et al., 2005; Halvorsen, 2005) or to design/change organizational forms by introducing new management techniques and/or rewards, or new work methods (Bekkers et al., 2006).

- Institutional Innovation Capacity - are fundamental transformations in the institutional relationships between organizations, institutions and other public sector actors, and more specific in public administration (Bekkers et al., 2006). 


\begin{tabular}{lll}
\hline Component & Item & Source \\
\hline \multirow{3}{*}{$\begin{array}{l}\text { CI_Serv.Proc } \\
\text { (Services and Processes })\end{array}$} & New/Changed Internal Services & $\begin{array}{l}\text { Wang and Ahmed, 2007; McKelvie and Davidson, 2009; Koch and Hauknes, 2005; } \\
\text { OECD, 2012; Bloch and Bugge, 2013 }\end{array}$ \\
\cline { 2 - 3 } & New/Changed External Services & Koch and Hauknes, 2005; Wang and Ahmed, 2007; OECD, 2012 \\
\cline { 2 - 3 } & New/Changed Internal Methods of Work & Wang and Ahmed, 2007; McKelvie and Davidson, 2009; OECD, 2012 \\
\hline $\begin{array}{ll}\text { CI_Org } \\
\text { (Organizational) }\end{array}$ & New/Changed Ways of Solving External Tasks & $\begin{array}{l}\text { Wang and Ahmed, 2007; Halvorsen et al., 2005; McKelvie and Davidson, 2009; } \\
\text { OECD, 2012 }\end{array}$ \\
\cline { 2 - 3 } & New/Changed Staff Incentive Methods & Halvorsen et al., 2005; Alberti and Bertucci, 2006; Koch and Hauknes, 2005; Hartley, 2005 \\
\hline \multirow{2}{*}{$\begin{array}{l}\text { CI_Inst } \\
\text { (Institutional) }\end{array}$} & New/Changed Public Policies & Moore et al., 1997; Koch and Hauknes, 2005; Bloch and Bugge, 2013 \\
\cline { 2 - 3 } & New/Changed Institutional Relations & $\begin{array}{l}\text { Halvorsen et al., 2005; Alberti and Bertucci, 2006; Koch and Hauknes, 2005; Hartley, } \\
\text { 2005; Bekkers }\end{array}$ \\
\hline
\end{tabular}

From empirical works based on intellectual capital, the structural capital, as its element and approached under three dimensions: structure for innovation, processes for innovation and organizational philosophy, was the framework proposed by the research. Structure is defined as an organizational framework, based on intangibles, that favor the existence or emergence of innovation. Processes are defined as routines and activities that stimulate or condition innovation, and, finally, organizational philosophy is understood here as a set of strategic assumptions, as if it were the organizational personality, formed by values, vision of the future, and organizational climate. The items are better understood as shown in Table 2. To measure structural capital and innovation capability we used a fivepoint linkert scale questionnaire ( 1 - not at all agree and 5 - totally agree).

Table 2: Structural Intellectual Capital Measures

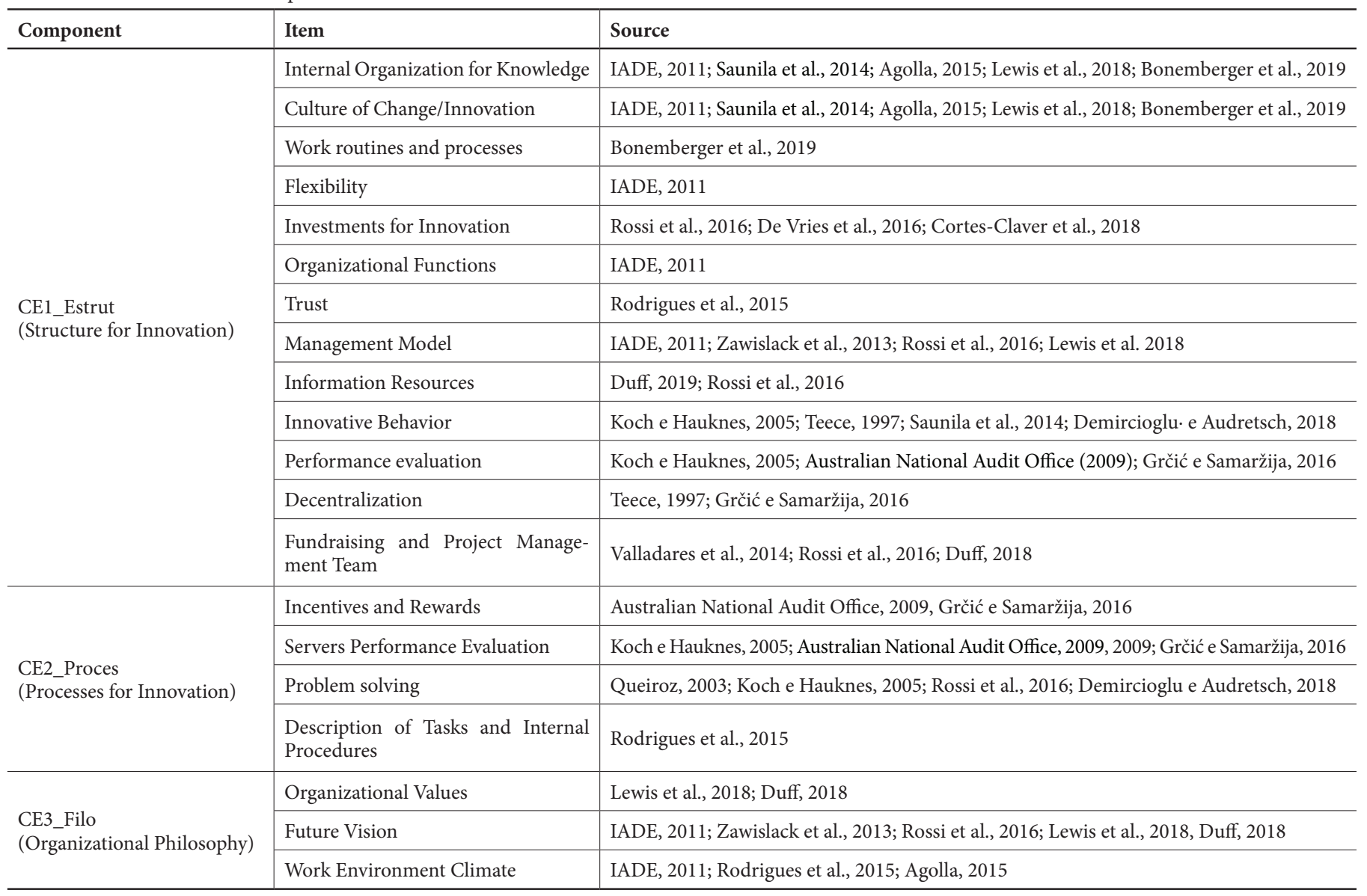

ISSN: 0718-2724. (http://jotmi.org) 


\subsection{Statistical technique}

The responses from temporary employees were not taken into account, considering that the responses from permanent employees presented more reliable indexes in relation to data normalization (standard deviation). Another qualitative aspect taken into consideration was that the permanent employees are less sensitive to changes in government because they have the prerogative of functional stability. Thus, the sample was reduced to 104 valid collections.

To define the constructs of structural intellectual capital and innovation capability, the exploratory analysis was used, through the PCA (principal component analysis). The variables that presented communalities lower than 0.4 were disregarded, for not being similar to the rest of the items. The factors were reduced to better explain the collected information, for such, the Kaiser method with a percentage higher than $50 \%$ clarifies the total variance.

Rotation was used on the structural capital items with the intention of adjusting the original items to the different axes and organizing them into appropriate factors. The validation of this technique was achieved by means of the Bartlett test and the Kaiser-Meyer and Okin coefficient (KMO). Cronbach's Alpha coefficient tested and proved the questionnaire's internal consistency, considering indexes above 0.6 as adequate (Hair Jr., et al, 2005).

To finally prove the hypothesis that originated the study, we used the techniques of correlation and linear regression, the latter also allowing us to evaluate and compare the direct effect of each independent variable on the dependent one. Finally, the process of data analysis and treatment, as well as evaluation, was carried out using the Statistical Package for the Social Sciences (IBM SPSS Statistics version 22 in Portuguese).

\section{Empirical Results and Discussions}

The empirical results were presented in two parts. Data reliability and exploratory factor analysis were the first step. Then we present the correlation and regression between the Structural Capital variables. First, data reliability and exploratory factor analysis were investigated, and then we analyze the correlation between the Structural Capital constructs and Innovation Capability, in order to answer the proposed hypotheses.

\section{Reliability}

Cronbach's Alpha coefficients presented indexes above 0.9 indicating high reliability and consistency of internal data (Hair Jr. et al., 2005), as shown in Table 3. The same authors state that an acceptable level of reliability (above 0.7 ) means that the respondents answered the questions consistently.

Table 3: Reliability Analysis - Cronbach's Alpha

\begin{tabular}{l|l|l}
\hline Constructs & Items & Alpha de Cronbach \\
\hline Structural Capital (SC) & 20 &, 942 \\
\hline Innovation Capacity (IC) & 8 &, 934 \\
\hline
\end{tabular}

\section{Exploratory Factor Analysis}

The technique reduced the data and organized it through factors. To this end, the Principal Components Analysis (PCA) was performed to also, relate the variables without determining to what extent the results coincide with the proposed model (Rodrigues et al., 2009).

The criterion used for statistical application was a cut-off of 0.40 , so that the factors would explain at least $50 \%$ of the proposed items. Then the constructs were distributed through Varimax rotation with Kaiser Normalization, obtaining the dimensions and their respective variables.

\section{Structural Intellectual Capital}

The data reduction in all Structural Capital items presented KMO (Kaiser-Meyer-Olkin) index suggesting a good correlation among the variables $(\mathrm{KMO}=.913)$. On the other hand, Bartlett's test of sphericity pointed to a significance level of 0.000 which rules out the hypothesis that the correlation matrix is the identity matrix $(\mathrm{p}<0.01)$. Therefore, the conclusion is that there is correlation between the variables. With the statistical endorsement of data reliability, it was possible to proceed and confirm the specific results of the principal components analysis, with 20 items, distributed in 3 common factors and, explained variance of $63.39 \%$, (Table 4 ). The distribution obtained the convergence of 4 interactions, according to Varimax rotation with Kaiser Normalization. 
Table 4: Structural Intellectual Capital Components

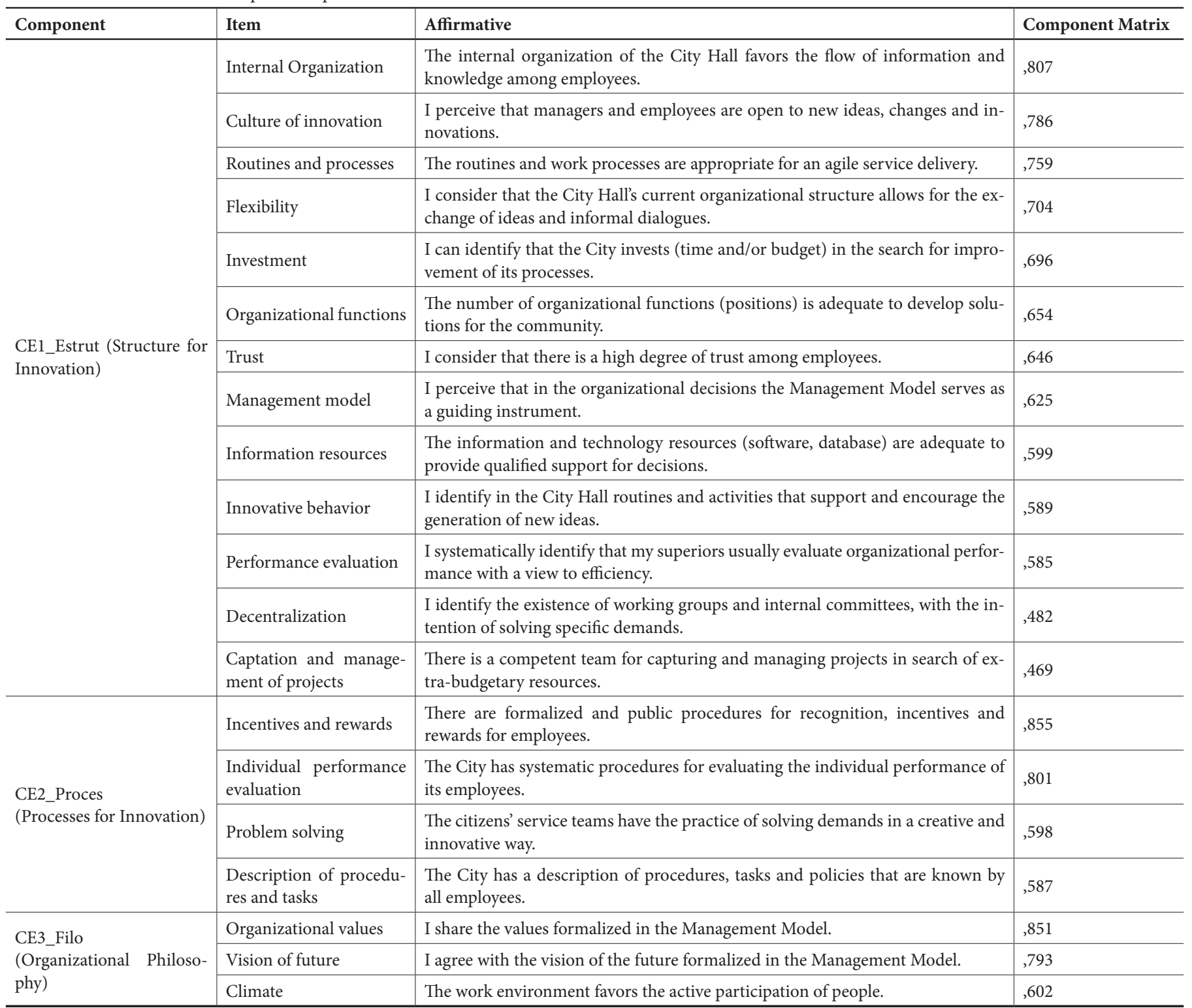

Service and Process Innovation Capability

The result of the PCA, with the same criteria applied to the Human Intellectual Capital elements, found a KMO (Kaiser-Meyer-Olkin) index with very good correlation between the variables $(\mathrm{KMO}=.835)$. Bartlett's sphericity, showed a significance of 0.000 which rejects the hypothesis that the correlation matrix is the identity matrix $(\mathrm{p}<0.01)$. Therefore the conclusion is that there is correlation between the element variables. Considering that the previous data confirm the statistical reliability, we proceeded to describe the results of the extracted factors. These presented 4 items, explained by a variance of $77 \%$ (Table 5). The distribution did not converge due to the fact that there was a single component.
Table 5: Service and Process Innovation Capability Components

\begin{tabular}{l|l|c}
\hline Component & Ítem & Component Matrix \\
\hline \multirow{4}{*}{$\begin{array}{l}\text { CI_Serv.Proc } \\
\text { (Services and Processes) }\end{array}$} & $\begin{array}{l}\text { New/Changed Internal } \\
\text { Services }\end{array}$ &, 883 \\
\cline { 2 - 3 } & $\begin{array}{l}\text { New/Changed External } \\
\text { Services }\end{array}$ & $\begin{array}{l}\text { New/Changed Internal } \\
\text { Methods of Working }\end{array}$ \\
\cline { 2 - 3 } & $\begin{array}{l}\text { New/Changed Ways of } \\
\text { Solving External Tasks }\end{array}$ &, 903 \\
\hline
\end{tabular}

Organizational Innovation Capability 
In analyzing these items, the PCA, with the same previous criteria, found a KMO (Kaiser-Meyer-Olkin) index that suggests acceptable correlation between the variables $(\mathrm{KMO}=.500)$. Bartlett's sphericity demonstrated a significance level of 0.000 which rejects the hypothesis that the correlation matrix is the identity matrix $(\mathrm{p}<0.01)$, proving there is correlation between the items. Noting that the previous data point to statistical reliability, we proceeded to describe the results of the extracted factors, explained by a variance of $81 \%$ (Table 6).

Table 6: Organizational Innovation Capability components

\begin{tabular}{l|l|c}
\hline Component & Item & Component Matrix \\
\hline \multirow{2}{*}{$\begin{array}{l}\text { CI_Org } \\
\text { (Organizational) }\end{array}$} & New/Changed Strategic Goals &, 765 \\
\cline { 2 - 3 } & $\begin{array}{l}\text { New/Changed Methods of } \\
\text { Incentive to Servers }\end{array}$ &, 963 \\
\hline
\end{tabular}

Institutional Innovation Capacity

The variable's PCA, with the same previous criteria, found a KMO (Kaiser-Meyer-Olkin) index that suggests acceptable correlation between the variables $(\mathrm{KMO}=.500)$. Bartlett's sphericity, demonstrated a significance level of 0.000 , which rules out the hypothesis that the correlation matrix is the identity matrix $(\mathrm{p}<0.01)$. Therefore, there is correlation between the two element items. The results of the extracted factors, showed 2 items, explained by a variance of $89.71 \%$ (Table 7 ).

Table 7: Institutional Innovation Capability components

\begin{tabular}{l|l|c}
\hline Component & Item & Component Matrix \\
\hline \multirow{3}{*}{$\begin{array}{l}\text { CI_Inst } \\
\text { (Institutional) }\end{array}$} & $\begin{array}{l}\text { CI. 7 - New/Modified Public } \\
\text { Policies }\end{array}$ & $\begin{array}{l}\text { CI. 8 - New/Changed Institutio- } \\
\text { nal Relations }\end{array}$ \\
\hline
\end{tabular}

Correlation and Regression

To study the influence between the structural intellectual capital and the innovation capability, regressions were carried out between the variables of the structural capital, with the proposed factors of the innovation capability in the public administration researched. The B's with values greater than 0.200 were selected. Thus, it was possible to demonstrate the existence of robust relations between the constructs, as illustrated in Tables 8, 9 and 10 .

Table 8: Regression Matrix: Structural Capital and Innovation Capacity Services and Processes

\begin{tabular}{c|c|c|c|c|c}
\hline & \multicolumn{2}{|c|}{ Non-standardised coefficients } & Standardised coefficients & \multirow{2}{*}{ t } & \\
\cline { 2 - 5 } & Standard Error & Beta & & 9,633 & \\
CE1_Struct &, 557 &, 058 &, 582 &, 000 &, 000 \\
CE2_Proces &, 339 &, 058 &, 354 &, 862 &, 000 \\
CE3_Philo &, 401 &, 058 &, 419 & 6,934 &, 000 \\
\hline
\end{tabular}

a. Variável Dependente: CI_Serv.Proc

It is possible to conclude that the Structure for innovation (.557 sig. 000) Processes (.339 sig. 000) and Organizational Philosophy (.401 sig. 000) are variables that make up the Structural Capital, and that influence positively, significantly and all have direct effects on the Ability to Innovate in Services and Processes, in the case studied.

Table 9: Regression Matrix: Structural Capital and Organizational Innovation Capability

\begin{tabular}{c|c|c|c|r|r}
\hline & \multicolumn{2}{|c|}{ Non-standardised coefficients } & Standardised coefficients & \multirow{2}{*}{ T } & \multirow{2}{*}{ Sig. } \\
\cline { 2 - 5 } & Standard Error & Beta &, 554 & 8,519 &, 000 \\
CE1_Struct &, 544 &, 064 &, 475 & 7,300 &, 000 \\
CE2_Proces &, 466 &, 064 &, 222 & 3,413 &, 001 \\
CE3_Philo &, 218 &, 064 &, 220 & \\
\hline
\end{tabular}

a.Variável Dependente: CI_Org

Regarding the dependent variable Organizational Innovation Capacity, the structural capital factors, calculated as independent variables: Structure (.544 sig. 000) Processes (.446 sig. 000) and Organizational
Philosophy (.218 sig.001) influence positively, significantly, and all, with direct effects on the ability to innovate, in the context of the research.

Table 10: Regression Matrix: Structural Capital and Institutional Innovativeness

\begin{tabular}{l|c|c|c|c|c}
\hline & \multicolumn{2}{|c|}{ Non-standardised coefficients } & Standardised coefficients & \multirow{2}{*}{ T } & \\
\cline { 2 - 5 } & Standard Error & Beta & & 7,292 &, 000 \\
\hline CE1_Struct &, 457 &, 063 &, 463 & 4,696 &, 000 \\
CE2_Proces &, 294 &, 063 &, 298 & 8,593 &, 000 \\
CE3_Philo &, 538 &, 063 &, 546 & \\
\hline
\end{tabular}

a. Variável Dependente: CI_Inst 
The indexes demonstrate that the structural capital factors: Structure (.457 sig. 000), Processes (.294 sig. 000) and Philosophy (.538 sig. $000)$ influence positively, significantly and with direct effects on the
Institutional Innovation Capacity, according to the answers of the managers of the researched municipal government.

Table 11: Summary of the Regression Model

\begin{tabular}{|c|c|c|c|c|c|}
\hline Model & $\mathbf{R}$ & R square & $\begin{array}{l}R \text { square } \\
\text { adjusted }\end{array}$ & $\begin{array}{l}\text { Standard error } \\
\text { of the estimate }\end{array}$ & Sig \\
\hline 1 - Structural Capital and Innovation Capability Services and Processes &, $799^{\mathrm{a}}$ & ,639 & ,628 & ,58397132 & 000 \\
\hline 3 - Structural Capital and Innovation Capability &, $775^{\mathrm{a}}$ & 601 &, 589 & ,63290522 & 000 \\
\hline
\end{tabular}

The demonstration of the regression (Table 11) between the structural intellectual capital (independent variable) and the innovation capacity of services and processes (dependent variable) showed a direct, significant and positive correlation (.799 sig. 000). As well as the same capital regressed to the dependent variable, organizational innovation capability, demonstrated positive and significant indexes (.763 sig. 000) and, still regressed to institutional capability the structural capital, also, revealed promising results (.775 sig. 000). Simply put, in all three models the R confirms the existence of a positive correlation between structural capital and the innovation capability constructs.
This argument is further reinforced by the R2 results $(, 639 ;, 581 ; 601)$ demonstrating that the innovation capability constructs (Services and Processes, Organizational and Institutional) can be predicted $(<50 \%)$ by the existing correlations between the factors in our model (independent and dependent variables).

Therefore, it is possible to state that the structural intellectual capital influences positively, significantly and directly the Capacity to innovate in the context of the local public administration studied, as, synthesized by Figure 4.

Figure 4: Framework - Influence of Structural Intellectual Capital on the Innovation Capacity of Local Public Administration

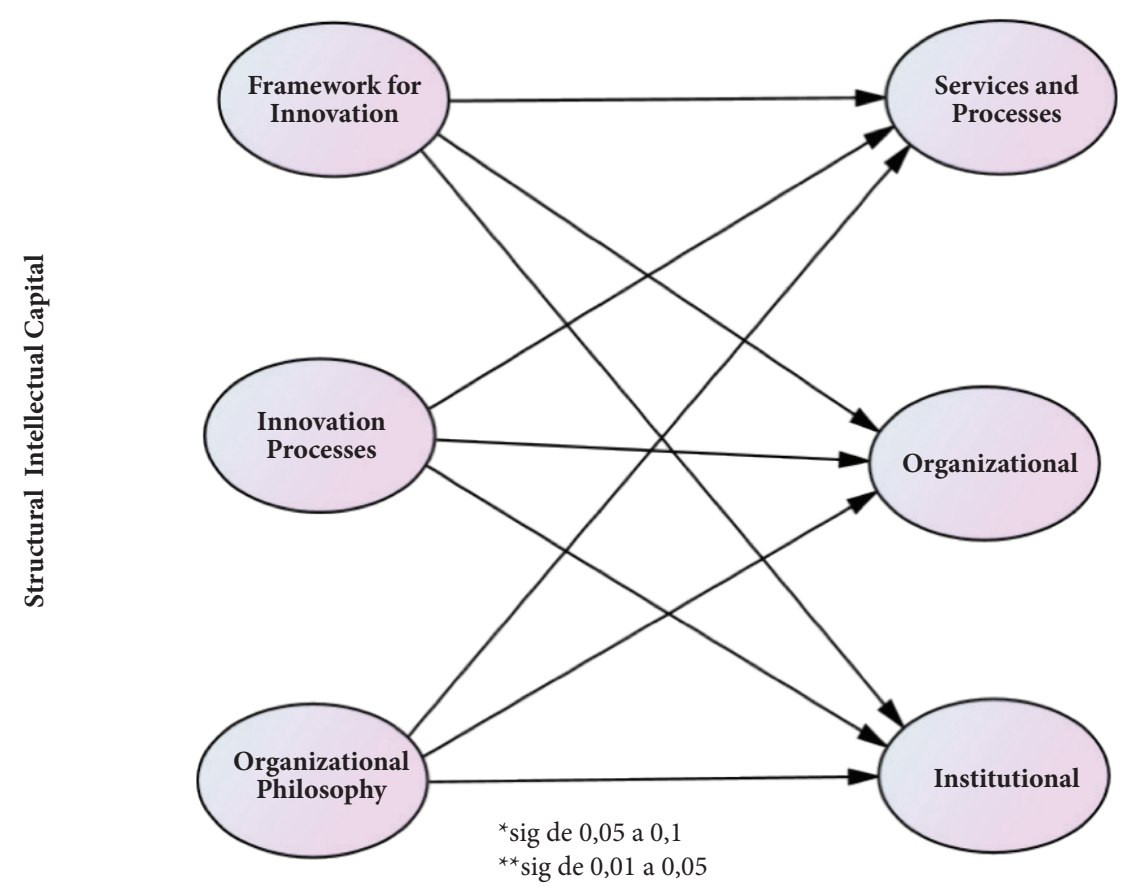

Prepared by the authors

Once the items and the correlations evident in the research question were unveiled, the hypotheses were organized (Table 12) in order to discuss the results in an organized manner, right afterwards. 
Table 12: Hypothesis Test

\begin{tabular}{l|c}
\hline Hypothesis & Situation \\
\hline $\begin{array}{l}\text { H1. The structure for innovation (ce1_estrut) } \\
\text { influences innovation capacity in local public } \\
\text { administration; }\end{array}$ & $\begin{array}{c}\text { CONFIRMED } \\
\text { Positive } \\
\text { Significant } \\
\text { Direct }\end{array}$ \\
\hline $\begin{array}{l}\text { H.2 The processes for innovation (ce2_proces) } \\
\text { influence innovation capacity in local public } \\
\text { administration; }\end{array}$ & $\begin{array}{c}\text { CONFIRMED } \\
\text { Positive }\end{array}$ \\
\hline $\begin{array}{l}\text { H.3 Orgnificant } \\
\text { influences innovation capacity in local public } \\
\text { administration. }\end{array}$ & Direct \\
\hline
\end{tabular}

H1. The structure for innovation influences the innovation capacity in the local public administration.

The hypothesis 1 of the research was confirmed, that is, the structure for innovation, presented by the researched City Hall influences positively, significantly and with direct effects, on innovation capacity in the three dimensions researched (services and processes, organizational and institutional). This result is similar to the indexes and confirmations obtained from researches in the private sector (Rodrigues et al., 2011; 2015; Baldridge y Burnham, 1975; Damanpour, 1991; McCann, 1991; Wan et al., 2005; Subramanian y Nilakanta, 1996).

The pro-innovation environment translated by variables such as organization, culture, routines, and innovative behavior, for example, has credibility with other research (Rodrigues et al, 2015; Gubiani, 2011; Cabrita 2006), albeit in other contexts. Cabrita (2006) argues that the knowledge produced must find available infrastructure in the organizational context for it to thrive and become collective. In other words, knowledge must extrapolate the individual intelligence of employees and become organizational routines and culture, promoting Human Capital retention. Dumay et al. (2016) agree with this argument and add that stimulating structural capital means extending the resources found in the organization itself, that is, what is left without employees, this includes database, routines, processes, culture, image and other organizational assets. Therefore, the structure for innovation is configured as an important variable and with direct, significant and positive effects on the ability to innovate, in the case of the public administration researched. In this sense, the structure for innovation is defined as the set of variables that represent the design, development, and organizational environment, suitable for modifying or creating new services and products, new or modified techniques and or organizational objectives, and also new or modified public policies and institutional relationships, in the context studied.

H2. The processes for innovation influence the capacity for innovation in local public administration.

The hypothesis 2 of the research was affirmative, that is, the processes for innovation, presented by the Municipality of Santiago, influence positively, significantly and with direct effects, the innovation capa- city in the three dimensions researched (services and processes, organizational and institutional). The results align with the findings of Lewis et al. (2018); Grčić and Samaržija (2016) and Demircioglu- and Audretsch (2018) who confirmed that internal management routines and procedures and people management reflect in innovation drivers, in view of making clear what each employee gains from the progress of the administration. Although, these gains in the public sector are most often not financial, it is certain that management by competencies, for example, clarifies and aligns goals, performance, and expectations between employees and the local public administration.

Therefore, the internal processes for innovation, in the specific case the formalized management instruments, serve as a kind of driver for the basic infrastructure of innovation, in a sector that is usually bureaucratic (Alosani et al., 2019) and with excessive use of standards and rules, as is the case of public administration in Municipalities, it seems to finally clarify its advantage, in the case of well outlined management instruments. In this way, processes for innovation is understood as the set of systematized variables that facilitate or encourage servants to modify or create new services and products, new or modified techniques and or organizational objectives, and also new or modified public policies and institutional relations, in the context studied.

H3. Organizational philosophy influences the ability to innovate in local public administration.

The third hypothesis of the research was confirmed, that is, organizational philosophy reflects and influences positively, directly and significantly the ability to innovate (services and processes, organizational, institutional) in local government. Molina and Palma (2004) state that the deliberation of planning aspects such as vision, mission, and values clarify the employees and facilitate change processes, obviously, because one has defined where to go. This seems to be the point in the public administration of the Latin Municipality. The management model built and in course for more than three administrations (elections) has significantly modified the previous directions, when it defined that the municipality would have as a future vision to consolidate itself as an educating city (Vieira and Aquino, 2015; Gadotti, 2006). Regardless of the sociological and/or ideological vision adopted, what is at stake are the organizational and public policy changes/innovations required to achieve the future vision and generate value, in line with the research of Gallego et.al. (2020) that mentions a direct relationship between strategic design and intellectual/structural capital.

It is necessary to consolidate the concept and the will to innovate, otherwise the innovation discourse tends to become a "fad". Korth (2007) cited by Rodrigues et al. (2009) states that without a culture that embraces knowledge and is consciously focused on creating it, innovation is nothing more than a "current concept". Therefore, organizational philosophy is defined as a construct of structural capital, responsible for guiding the organizational process and structure, influencing the ability to modify/innovate services and processes, organizational goals and incentives, and public policies and relations of the local public administration studied. 


\section{Conclusions, limitations and future research}

It was confirmed that structural intellectual capital has a positive, significant and direct effect on innovation capability, in its three dimensions, in the studied municipal public administration. With this, the general objective and the hypotheses of the research, were analyzed and confirmed.

The structural capital factors, innovation structure (CE1_Estrut), processes (CE2_Proces) and organizational philosophy (CE3_Filo), have an influence (positive, significant and direct) on the three constructs of innovation capacity in the local public administration. The results are aligned with private sector research, but present novelties in the way that the factors are organized, through principal component analysis, intellectual capital, but mainly innovation capability, which advanced on the findings of Lewis et al. (2018); Grčić and Samaržija (2016) and Demircioglu- and Audretsch (2018) who, until then, had analyzed this capability only through the qualitative bias. The factors of intellectual capital and especially innovation capability services and processes (CI_ Serv_Proces), organizational (CI_Org) and institutional (CI_Inst), are interesting novelties to advance the research of the subjects, constituting novel theoretical/methodological contribution.

From a practical point of view, of management contributions, having found that the greater the structural capital, the greater the possibilities for innovation, it can be seen that investments in structure for innovation, not a department per se, but actions that stimulate collective thinking and resolutions, integrating secretariats or departments, interrelating actions, and, above all, valuing the work together, are activities that do not depend on the budget. These initiatives contemplate ideas of structuring a collective intelligence (Leimeister, 2010; Malone, Laubacher and Dellarocas, 2010; Surowiecki, 2004) internally, giving support and generating collective knowledge, with the intention of going beyond the record of organizational memory, structuring an environment and a climate of innovation and creativity based on collaboration. The structuring of a Personnel Management department, and not only a Personnel Department, may technically support the management, besides strategically aligning actions and results, with financial incentives for the employees.

The management model developed by the City Hall exemplifies in part that the collectivity tends to unify the management, including sharing results, and also creating unity between stable and political servants. In this sense, it can be seen that the strategic project had an impact on the improvement of structural and intellectual capital processes (Gallego et al., 2020), influencing committees and participatory actions of the government with the community, towards the vision of the Educating City.

The biggest limitation of the research was the fact that it was a case study, thus, its results cannot be generalized. In the methodological replication in studies with the same objectives, even within the scope of local public administration, it is necessary to consider the context and place of application, considering that each location has its own legal institutions and cultures.
As future research it is possible to confirm the exploratory model through structural equations, thus obtaining higher levels of reliability and explanation in the relationships between the variables. It is also possible to investigate the effective contribution of planning, management model and/or governmental planning and its influence on the ability to innovate in public administration. Finally, new approaches such as environmental social governance (ESG), for example, can compose new variables of outputs, considering as input items the structural capital or the innovation capacity, correlating them with sustainability, in the scope of local public administration.

Finally, the article brought as novelty the confirmation that structural intellectual capital has a positive, significant and direct effect on the ability to innovate in public administration, expanding possibilities of generalizations in the theoretical field. Furthermore, the findings show to the local government that investments in the organizational environment will possibly have positive effects on innovation, and consequently, on the aggregation of value for the local community.

\section{References}

Agolla, J.E. (2015) Assessment of innovation in kenya's public sector organisations. Thesis submitted for the degree of Doctor of Philosophy in Business Management in the Faculty of Commerce and Administration at the Mafikeng Campus of the North -West University.

Alberti, A.; Bertucci, G. (2006) Innovations in Governance and Public Administration:Replicating What Works. New York.

Alosani, M.S., Yusoff, R. and Al-Dhaafri, H. (2019), "The effect of innovation and strategic planning on enhancing organizational performance of Dubai Police", Innovation \& Management Review, Vol. 17 No. 1, pp. 2-24. https://doi.org/10.1108/INMR-06-2018-0039.

Australian National Audit Office (2009). Innovation in the Public Sector: enabling better performance, driving new directions. Better Practice Guide. Camberra. Recuperado em 07 abril, 2013, de http:// www.anao.gov.au/bpg-innovation/pdf/BPG-Innovation.pdf.

Baldridge, J. V. Y Burnham, R. A. (1975): “Organizational Innovation: Individual, Organizational, and Environmental Impacts”, Administrative Science Quarterly, vol. 20, n. 2, pp. 165-176.

Bekkers V., van Duivenboden H., and M. Thaens (2006), Public Innovation and Communication technology: relevant backgrounds and concepts, in Bekkers V. van Duivenboden H. and Thaens M. (eds), Information and Communication Technology and Public Innovation, IOS Press, Amsterdam/Berlin/Oxford/Tokyo/Washington DC, pp. 3-21.

Bloch, C., Bugge, M.M., (2013) Public sector innovation, From theory to measurement. Struct. Change Econ. Dyn. (2013), http://dx.doi. org/10.1016/j.strueco.2013.06.008.

Bonemberger, A.M., Dalla Corte, V.F., Basso, K., Sonza, I. (2019) The intellectual capital in public administration. Revista Brasileira de Gestão e Desenvolvimento Regional G\&DR. V. 15, N. 3, P. 3-16, maiago. Taubaté, SP, Brasil. ISSN: 1809-239X. 
Bontis, N. (1999): “Managing Organizational Knowledge by Diagnosing Intellectual Capital: Framing and advancing the state of the field", International Journal of Technology Management, vol. 18, n. 5/6/7/8, pp. 433-462.

Cabrita, M. R. (2006): Capital Intelectual e desempenho organizacional no sector bancário português, Tesis Doctoral defendida en la Universidade Técnica de Lisboa.

Claver-Cortes, E., Zaragoza-Saez, P., Gonzalez-Illescas, M. (2018) Intellectual capital management: An approach to organizational practices in Ecuador. Intangible Capital IC, 2018 - 14(2): 270-285 - Online ISSN: 1697-9818 - Print ISSN: 2014-3214 https://doi.org/10.3926/ic.1158

Damanpour, F. (1991): "Organizational innovation: a meta analisis of effects and determinantes and moderators", Academy of Management Journal, vol. 34, n. 3, pp. 555-590.

Demircioglu, M., Audretsch D. (2018): Conditions for complex innovations: evidence from public organizations, The Journal of Technology Transfer https://doi.org/10.1007/s10961-018-9701-5

Díaz, N.; Aguiar, I. Y De Saá, P. (2006): El Conocimiento Organizativo Tecnológico y la Capacidad de Innovación. Evidencia para la Empresa Industrial Española, Cuadernos de Economía y Dirección de la Empresa, №. 27, pp. 33-60.

Duff, A. (2018) Intellectual capital disclosure: evidence from UK accounting firms. Journal of Intellectual Capital Vol. 19 No. 4, pp. 768 786 DOI 10.1108/JIC-06-2017-0079.

Dumay, J. (2016) A critical reflection on the future of intellectual capital: from reporting to disclosure, Journal of Intellectual Capital, Vol. 17 No. 1, 2016, pp. 168-184, 1469-1930, DOI 10.1108/JIC-08-2015-0072.

Edvinsson, L.; Malone, M. S. (1998) Capital Intelectual, Ed. Makron Books, São Paulo, 1998.

European Commission. (2013) Powering european public sector innovation: towards a new architecture. Report of the Expert Group on Public Sector Innovation, Directorate General for Research and Innovation, Innovation Union, European Commission, Brussels.

Gadotti, M. (2006) A escola na cidade que educa. Cadernos Cenpec 2006 n. 1.

Gallego, C., Mejía, G.M. and Calderón, G. (2020), "Strategic design: origins and contributions to intellectual capital in organizations", Journal of Intellectual Capital, Vol. 21 No. 6, pp. 873-891. https://doi. org/10.1108/JIC-10-2019-0234

Grčić Fabić, M.; Zekić, Z; Samaržija, L. (2016). Implementation of management innovation - a precondition for the development of local government effectiveness: evidence from Croatia. Administratie si Management Public, (27), 7-29.
Gubiani, J. S. (2011) Modelo para diagnosticar a influência do Capital Intelectual no potencial de inovação nas universidades. 2011. Tese (Doutorado em Engenharia e Gestão do Conhecimento) - Universidade Federal de Santa Catarina, Florianópolis.

Hair, J. F.; Babin, B.; Money, A. H. Y Samouel, P. (2005), Tradução Lene Belon Ribeiro - Porto Alegre: Bookman.

HALVORSEN, T. et al. (2005), Sobre as diferenças entre inovação dos sectores público e privado. Oslo: Passo Nifu. (Publin Report, n. D9).

Hartley, J. (2005). "Innovation in Governance and Public Services": Passado e Presente", em Public Money \& Management, vol. 25, no. 1, Janeiro de 2005, pp 27-34.

I.A.D.E. (2011): "Modelo Intellectus: medición y gestión del Capital Intelectual”: C.I.C.- I.A.D.E. (UAM). Madrid.

Jassawalla, A. R. Y Sashittal, H. C. (2003): “The DNA of culture that promote product innovation", Ivey Business Journal Online, vol. 1, pp. 1-1.

Kamaruddin, K. and Abeysekera, I. (2013), Intellectual Capital and Public Sector Performance, Emerald Group Publishing Limited.

Kaplan, R. S. Y Norton, D. (1996): "Using Balance Scorecard as an strategic management system”, Harvard Business Review, vol. 74, n. 1, pp. 75-85.

Kaplan, R. S. Y Norton, D. (1999): Cuadro de Mando Integral (The Balanced Scorecard), Gestión 2000, España, 2a edición.

Kaplan, R. S.; Norton, D. P. (1997): A Estratégia em Acção: Balanced Scorecard. Rio de Janeiro: Campus.

Koch P., Cunningham P., Schwabsky N., Hauknes J. (2005), Innovation in the Public sector. Resumo e recomendações políticas. Oslo: Publin Report n D24.

Koch, P.; Hauknes, J. (2005), On innovation in the public sector. Oslo: PASSO NIFU.

Korth, K. (2007): "Re-establishing the importance of the Learning Organizations", Automotive Design \& Production, vol. 119, n. 11, pp. 12-12.

Jardón, C.M.F.; Silva, A. F.C. (2020) Valor acrescentado do capital estrutural à cadeia de valor da madeira e indústrias relacionadas. Rev. Adm. UFSM, Santa Maria, v. 13, número 4, p. 895-917. DOI: 10.5902/ 1983465955325.

Leimeister, J.M., 2010. Kollektive intelligenz. Business and Information Systems Engineering, 52(4), pp.239-242.

Lewis, J. M., Ricard, L. M., \& Klijn, E. H. (2018). Como os motores da inovação, o trabalho em rede e a liderança moldam a capacidade de inovação do sector público. International Review of Administrative Sciences, 84(2), 288-307. 
Malone, T.W., Laubacher, R. e Dellarocas, C., 2010. O genoma da inteligência colectiva. MIT Sloan Management Review, 51(3), pp.21-31.

Martin de Castro, G., Alama, E., Navas, J. Y Lopez, P. (2009): El papel del capital intelectual en la innovación tecnológica: Una aplicación a las empresas de servicios profesionales de España, Cuadernos de Economía y Dirección de la Empresa, Vol. 40, pp. 83-110.

Massaro, M., Dumay, J.; Garlatti, A. (2015) Public sector knowledge management: a structured literature review. Journal of knowledge management vol. 19 no. 3 2015, pp. 530-558, ISSN 1367-3270 DOI 10.1108/JKM-11-2014-0466.

Mccann, J. E. (1991): "Design principles for an innovating company", Academy of Management Executive, vol. 5, n. 2, pp. 76-87.

McKelvie, A., \& Davidsson, P. (2009). Da base de recursos às capacidades dinâmicas: uma investigação de novas empresas. British Journal of Management, 20(Suppl.), S63-S80. doi: 10.1111/j.14678551.2008.00613.x

Meirelles, D. S.; Camargo, A. A. B. (2014). Capacidades dinâmicas: O que são e como identificá-las? RAC, 18, 41-64. doi:10.1590/19827849rac2014 1289.

Molina-Palma, M. A. (2004): A capacidade de inovação como formadora de valor: análise dos vetores de valor em empresas brasileiras de biotecnologia, Tesis doctoral defendida en la Universidade de São Paulo.

Rodrigues, H.S., Jardón,C.M.F., Dorrego,P.F.(2015) Relation between intellectual capital and the product process innovation. Int. J. Knowledge-Based Development, Vol. 6, No. 1.

Roos, G. (2017) "Knowledge management, intellectual capital, structural holes, economic complexity and national prosperity", Journal of Intellectual Capital, Vol. 18 Issue: 4, pp.745-770, https://doi.org/10.1108/ JIC-07-2016-000. https://doi.org/10.1108/JIC-07-2016-0072

Rossi, F.M; Francesca Citro, F.; Bisogno, M. (2016) Intellectual capital in action: evidence from Italian local governments. Journal of Intellectual Capital. Vol. 17 No. 4, 2016. pp. 696-713.

Saunila, M., Pekkola, S., Ukko, J. (2014) The relationship between innovation capability and performance: The moderating effect of measurement. International Journal of Productivity and Performance Management 63(2):234-249 DOI: 10.1108/IJPPM-04-2013-0065
Stewart, T. A. (1998): La nueva riqueza de las organizaciones: el Capital Intelectual, Ediciones Granica, Barcelona.

Subramanian, A. Y Nilakanta, A. (1996): "Organizational Innovativeness: exploring the relationship between organizational determinants of Innovation, types of Innovations, and measures of organizational performance", Omega, vol. 24, n. 6, pp. 631-647.

Surowiecki, J.M., 2004. A Sabedoria das Multidões: Why the Many Are Smarter Than the Few and How Collective Wisdom Shapes Business, Economies, Societies and Nations. Nova Iorque, NY: Duplo dia.

Teece, D,J.; Pisano, G. e SHUEN, A. (1997) Dynamic Capabilities And Strategic Management, Strategic Management Journal, Vol. 18:7, 509-533.

Valladares, P. S. D.,Vasconcellos, M.A.,\&Di Serio, L. (2014). Capacidade de Inovação: Revisão sistemática da Literatura. RAC -Revista de Administração Contemporânea, 18(5): 598-626, Set./Out.

Vasconcellos, M. A. De; Valladares, P. S. D. A; Di Serio, L. C. (2016) Capacidade de inovação: revisão sistemática da literatura. Revista de Administração Contemporânea, v. 18, n. 5, p. 598-626.

Viedma Marti, J. M. (2002): Innovation Capacity Benchmarking System (I.C.B.S.). Em N. Bontis (Eds.), World congress on Intellectual Capital Readings (pp. 243-265): Butterworth-Heinemann.

Vieira, E.; Aquino, J.G. (2015) Sobre a pedagogia da experiência urbana: O projecto da cidade educativa. Educação Unisinos (3):313-324, setembro/dezembro Unisinos - doi: 10.4013/edu.2015.193.02.

Wan, D.; Ong, C. H. Y Lee, F. (2005): "Determinants of firm innovation in Singapore", Technovation, vol. 25, pp. 261-268.

Wang, C. e Ahmed, P. (2007). Dynamic capabilities: a review and research agenda.International Journal of Management Reviews, 9, 31-51.

WU, S.; LIN, L., HSU, M., (2007), Intellectual capital, capacidades dinâmicas e desempenho inovador das organizações, International Journal of Technology Managmenent, 39(3-4), 279-296.

Zawislak, P.A.; Marins, L. M.. (2013) A Atividade de Inovação e sua Mensuração em Firmas de Economias Emergentes: Contribuições para uma Medida Geral de Inovação. Em: BRUNO-FARIA, Maria de Fátima (Org.); VARGAS, Eduardo R. de (Org.); MARTÍNEZ, Albertina Mitjáns (Org.). Criatividade e Inovação nas Organizações. 1 ed., São Paulo: Atlas, 2013. p. 156-174

Zollo, M.; Winter, S. G. (2002) Deliberate learning and the evolution of dynamic capabilities. Organization Science, v. 13, n. 3, p. 339-351. 
